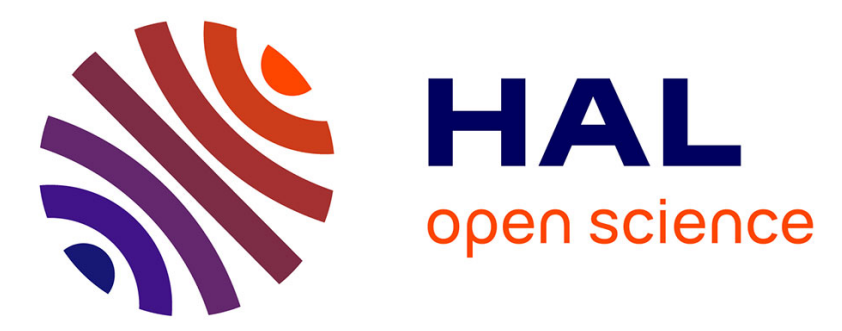

\title{
Genetic variability of strains assessed by PCR-RFLP analysis of polymorphic membrane protein-encoding genes
}

\author{
Michelle Sait, Ewan M. Clark, Nicholas Wheelhouse, Lucy Spalding, Morag \\ Livingstone, Konrad Sachse, Bryan K. Markey, Simone Magnino, Victoria I. \\ Siarkou, Evangelia Vretou, et al.
}

\section{To cite this version:}

Michelle Sait, Ewan M. Clark, Nicholas Wheelhouse, Lucy Spalding, Morag Livingstone, et al.. Genetic variability of strains assessed by PCR-RFLP analysis of polymorphic membrane proteinencoding genes. Veterinary Microbiology, 2011, 151 (3-4), pp.284. 10.1016/j.vetmic.2011.03.005 . hal-00717097

\section{HAL Id: hal-00717097 https://hal.science/hal-00717097}

Submitted on 12 Jul 2012

HAL is a multi-disciplinary open access archive for the deposit and dissemination of scientific research documents, whether they are published or not. The documents may come from teaching and research institutions in France or abroad, or from public or private research centers.
L'archive ouverte pluridisciplinaire HAL, est destinée au dépôt et à la diffusion de documents scientifiques de niveau recherche, publiés ou non, émanant des établissements d'enseignement et de recherche français ou étrangers, des laboratoires publics ou privés. 


\section{Accepted Manuscript}

Title: Genetic variability of Chlamydophila abortus strains assessed by PCR-RFLP analysis of polymorphic membrane protein-encoding genes

Authors: Michelle Sait, Ewan M. Clark, Nicholas Wheelhouse, Lucy Spalding, Morag Livingstone, Konrad

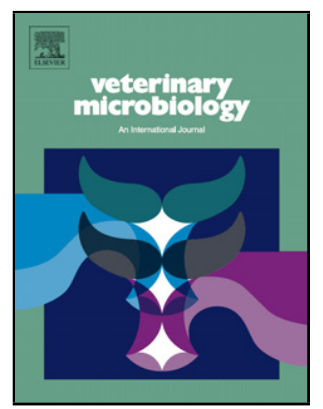
Sachse, Bryan K. Markey, Simone Magnino, Victoria I.

Siarkou, Evangelia Vretou, María R. Caro, Raja Yaga, F. Alex

Lainson, David G.E. Smith, Frank Wright, David Longbottom

PII: $\quad$ S0378-1135(11)00143-X

DOI: $\quad$ doi:10.1016/j.vetmic.2011.03.005

Reference: $\quad$ VETMIC 5228

To appear in: $\quad$ VETMIC

Received date: $\quad 25-1-2011$

Revised date: $\quad 1-3-2011$

Accepted date: $\quad$ 2-3-2011

Please cite this article as: Sait, M., Clark, E.M., Wheelhouse, N., Spalding, L., Livingstone, M., Sachse, K., Markey, B.K., Magnino, S., Siarkou, V.I., Vretou, E., Caro, M.R., Yaga, R., Lainson, F.A., Smith, D.G.E., Wright, F., Longbottom, D., Genetic variability of Chlamydophila abortus strains assessed by PCR-RFLP analysis of polymorphic membrane protein-encoding genes, Veterinary Microbiology (2010), doi:10.1016/j.vetmic.2011.03.005

This is a PDF file of an unedited manuscript that has been accepted for publication. As a service to our customers we are providing this early version of the manuscript. The manuscript will undergo copyediting, typesetting, and review of the resulting proof before it is published in its final form. Please note that during the production process errors may be discovered which could affect the content, and all legal disclaimers that apply to the journal pertain. 
1 Genetic variability of Chlamydophila abortus strains assessed by PCR-RFLP analysis of

2 polymorphic membrane protein-encoding genes

3

4 Michelle Sait ${ }^{\mathrm{a}, 1}$, Ewan M. Clark ${ }^{\mathrm{a}, 1,2}$, Nicholas Wheelhouse $^{\mathrm{a}}$, Lucy Spalding ${ }^{\mathrm{a}}$, Morag

5 Livingstone $^{\mathrm{a}}$, Konrad Sachse ${ }^{\mathrm{b}}$, Bryan K. Markey ${ }^{\mathrm{c}}$, Simone Magnino ${ }^{\mathrm{d}}$, Victoria I. Siarkou ${ }^{\mathrm{e}}$,

6 Evangelia Vretou ${ }^{\mathrm{f}}$, María R. Caro ${ }^{\mathrm{g}}$, Raja Yaga ${ }^{\mathrm{a}}$, F. Alex Lainson ${ }^{\mathrm{a}}$, David G.E. Smith ${ }^{\mathrm{a}, \mathrm{h}}$, Frank

$7 \quad$ Wright $^{\mathrm{i}}$, David Longbottom ${ }^{\mathrm{a}}$

9 a Moredun Research Institute, Pentlands Science Park, Bush Loan, Edinburgh, Midlothian, EH26

$10 \quad$ OPZ, UK

$11{ }^{\mathrm{b}}$ Friedrich-Loeffler-Institut (Federal Research Institute for Animal Health), Naumburger Str.

$1296 a, 07743$ Jena, Germany

$13{ }^{\mathrm{c}}$ School of Agriculture, Food Science and Veterinary Medicine, University College Dublin,

14 Belfield, Dublin 4, Ireland

15 d Istituto Zooprofilattico Sperimentale della Lombardia e dell'Emilia Romagna "Bruno

16 Ubertini”, National Reference Laboratory for Animal Chlamydioses, Sezione Diagnostica di

17 Pavia, Strada Campeggi 61, 27100 Pavia, Italy

$18{ }^{\mathrm{e}}$ Laboratory of Microbiology and Infectious Diseases, Faculty of Veterinary Medicine, Aristotle

19 University of Thessaloniki, University Campus, GR-54124, Thessaloniki, Greece

$20 \quad{ }^{\mathrm{f}}$ Laboratory of Biotechnology, Hellenic Pasteur Institute, Vassilissis Sofias Avenue 127, 11521

21 Athens, Greece

$22{ }^{\mathrm{g}}$ Departamento de Sanidad Animal, Facultad de Veterinaria, Universidad de Murcia, Campus de

23 Espinardo, 30100 Murcia, Spain 
$24^{\mathrm{h}}$ Institute of Infection, Immunity and Inflammation. College of Medical, Veterinary and Life

25 Sciences, University of Glasgow Garscube Estate, Bearsden Road, Glasgow G61 1QH, UK

$26 \quad{ }^{\text {i }}$ Biomathematics \& Statistics Scotland, Invergowrie, Dundee, DD2 5DA, UK

27

28

29 *Corresponding author: Tel.: +44 131445 5111; fax +44 1314456235.

$30 \quad$ E-mail address: michelle.sait@moredun.ac.uk

31

$32{ }^{1}$ These authors contributed equally to this work.

332 Present address: BigDNA, Wallace Building, Roslin BioCentre, Roslin, Midlothian, EH25 9PP, 34 UK.

35

36 Keywords: Chlamydophila abortus, restriction fragment length polymorphism, polymorphic

37 outer membrane protein.

38 


\section{Abstract}

This study used PCR-RFLP to investigate the genetic variability of $p m p$-encoding genes

41 from fifty-two Chlamydophila abortus (C. abortus) strains originating from abortion cases from

42 various geographical regions and host species. Six primer pairs were used to PCR-amplify DNA

43 fragments encoding eighteen pmps. PCR products were digested using four restriction

44 endonucleases and Bayesian methodologies were used to compare RFLP profiles and assign

45 strains to a RFLP genotype. Strains could be assigned to 2 genotypes in the region encoding

46 pmp18D, 3 genotypes in the regions encoding pmp1A-pmp2B, pmp3E-pmp6H and $p m p 11 G$ -

47 pmp15G, 4 genotypes in the region encoding $p m p 7 G-p m p 10 G$ and 5 genotypes in the region

48 encoding pmp16G-pmp17G. In all regions, the majority of strains $(88.4 \%-96.1 \%)$ had the same

49 genotype as the reference strain S26/3. No correlation could be made between genotype, host

50 species or geographical origin except for the two variant Greek strains, LLG and POS, which

51 formed a discrete genotype in all $\mathrm{pmp}$-encoding regions except $\mathrm{pmp} 18 \mathrm{D}$. Relative rates of

52 evolution calculated for each $\mathrm{pmp}$-encoding gene locus suggest that differing selective pressures

53 and functional constraints may exist on C. abortus polymorphic membrane proteins. These

54 findings suggest that although intraspecies heterogeneity of pmp-encoding genes in C. abortus is

55 low, the sequence heterogeneity should be an important consideration when using pmps as the

56 basis for novel diagnostics or vaccine development. 


\section{Introduction}

Ovine Enzootic Abortion (OEA) is an economically important disease accounting for approximately $43 \%$ of diagnosed abortions in sheep in the UK. The aetiological agent, Chlamydophila abortus (formerly Chlamydia psittaci serotype 1), can also cause abortion in cattle and pigs and poses a zoonotic risk to pregnant women (Longbottom and Coulter, 2003).

The genetic heterogeneity of $C$. abortus has been reported to be low, with methods based on the cross-reactivity of monoclonal antibodies, Restriction Fragment Length Polymorphism (RFLP) and the phylogenetic analysis of 16S rRNA genes, failing to differentiate strains based on host, pathotype or geographical origin (Denamur et al., 1991; Everett et al., 1999; Salinas et al., 1995). More recently, methods such as Multiple Loci VNTR Analysis (MLVA) and Multi Locus Sequence Typing (MLST), have allowed the differentiation of C. abortus strains into novel genotypes (Laroucau et al., 2009; Pannekoek et al., 2010) that were partly related to

71 geographical origin (Laroucau et al., 2009).

Genes encoding polymorphic membrane proteins (pmps) have been identified in all

73 members of the family Chlamydiaceae. In C. abortus there are 18 pmp-encoding genes that are

74 arranged as four loci composed of a single gene, two gene pairs and a large cluster of 13 genes

75 (Thomson et al., 2005). Polymorphic membrane proteins have been implicated in chlamydial

76 adhesion (Wehrl et al., 2004; Crane et al., 2006; Mölleken et al 2010), tissue tropism (Stothard et

77 al., 2003; Gomes et al., 2006) and the induction of immune responses (Mygind et al., 2004;

78 Wehrl et al., 2004; Livingstone et al., 2005) making them potential diagnostic and vaccine

79 targets (Longbottom and Livingstone, 2006; Sachse et al., 2008). The purpose of this study was to

80 analyse the genetic diversity of pmp-encoding loci from C. abortus isolates using PCR-RFLP

81 and determine whether strains could be distinguished by geographical origin or host species. 


\section{2. Materials \& Methods}

2.1 Propagation of C. abortus and gDNA preparation

Fifty-two C. abortus strains isolated from various host species and geographical regions were used in this study (Table 1). Strains were propagated as previously described (Graham et

87 al., 1995) and genomic DNA extracted using a Wizard Genomic DNA isolation kit (Promega).

\subsection{PCR amplification of pmp-encoding loci}

90 Oligonucleotide primers targeting the 18 pmp-encoding genes of C. abortus S26/3

91 [NC_004552] were designed using Lasergene 8 PrimerSelect software (DNASTAR). Three pmp-

92 encoding loci encoding one or two genes in tandem were PCR-amplified as single fragments and

93 are referred to in this study as BA (pmp1B-pmp2A), 16-17 (pmp16G-pmp17G) and 18D

94 (pmp18D). The locus encoding 13 pmps was PCR-amplified as three fragments which are

95 referred to in this study as EH (pmp3E-pmp6H), HG (pmp6H-pmp10G) and G (pmp11G-

96 pmp15G).

97 PCR amplification mixes comprised $1 \times$ Expand PCR buffer 3 (Roche Applied Sciences),

$98500 \mu \mathrm{M}$ dNTPs, $300 \mathrm{~nm}$ each primer (see Table 2), 0.075 U Expand Long Template Polymerase

99 (Roche Applied Sciences), and 20-100 ng C. abortus gDNA made up to a $25 \mu$ l final volume

100 using nuclease free water. PCR consisted of 1 cycle at $94^{\circ} \mathrm{C}$ for 2 min followed by 10 cycles of

$10194^{\circ} \mathrm{C}$ for $10 \mathrm{~s}, 51.9^{\circ} \mathrm{C}$ for $30 \mathrm{~s}$ and $68^{\circ} \mathrm{C}$ for $15 \mathrm{~min}$. A second amplification stage consisted of

10220 cycles of $94^{\circ} \mathrm{C}$ for $10 \mathrm{~s}, 51.9^{\circ} \mathrm{C}$ for $30 \mathrm{~s}$ and $68^{\circ} \mathrm{C}$ for $15 \mathrm{~min}$ with a $20 \mathrm{~s}$ increment per cycle

103 followed by one cycle of $68^{\circ} \mathrm{C}$ for $7 \mathrm{~min}$. Efficiency of amplification was assessed by agarose

104 gel electrophoresis using 0.8\% TAE-agarose gels containing $1 \times$ GelRed (Biotium Inc). 


\subsection{Restriction Fragment Length Polymorphism (RFLP)}

Restriction endonuclease (RE) digestions were performed using MboII (New England

108 Biolabs), HaeIII (New England Biolabs), RsaI (Roche Applied Sciences) and AluI (Roche

109 Applied Sciences). Restriction endonuclease digestion reactions consisted of $1 \times$ buffer, $5 \mathrm{U}$ of

110 the appropriate RE and 5 $\mu 1$ of PCR-amplified DNA. Restriction endonuclease digests were

111 incubated at $37^{\circ} \mathrm{C}$ for $2 \mathrm{~h}$. Five microlitres of each RE digest were electrophoresed on a $1.5 \%$

112 TAE-agarose gel containing $1 \times$ GelRed for $180 \mathrm{~min}$ or until the dye front had migrated to at least

$11315 \mathrm{~cm}$ from the sample wells. Gels were visualised under UV light and imaged using an

114 AlphaImager 2200 (Alpha Innotech).

\subsection{Data analysis}

117 Restriction fragment length polymorphism gel images were imported into Bionumerics

118 software (version 5.10, Applied Maths) and bands detected using default settings. The migration

119 of each restriction fragment (RF) was expressed as a proportion of the total distance run on the

120 gel, and strains were scored for the presence or absence of each RF generated with each of the

121 four REs. RF positions were normalized to account for inter-gel variation using the RFLP

122 profiles generated by the reference strain $\mathrm{S} 26 / 3$. The variation seen in technical replicates of

123 S26/3 was also used as a general estimate of variation among technical replicates and guided the

124 allocation of fragments to bins. The data were checked for errors and also evidence of horizontal

125 gene transfer (HGT) using the NeighborNet method (Bryant and Moulton, 2004) available in the

126 SplitsTree package (Huson and Bryant, 2006). Seventy of the 542 RFs that could not be

127 unambiguously assigned were removed from the analysis. This resulted in a 0-1 data matrix of 
128

129

130

131

132

133

134

135

136

137

138

139

140

141

142 the value of the rate parameter specified for the exponential prior on branch lengths was altered

143 to be 100 rather than the default value of 10 due to the observation of very high PSRF values for

144 the relative rate parameters for each region. This setting reflects a prior belief that branch lengths

145 are short (the rate parameter is the inverse of its mean). All analyses were then carried out with

146 this altered branch length prior distribution. The PSRF values of 93\% (211 out of the 226) of the

147 taxon bipartition parameters were less than 1.20 (the maximum value was 2.04 and 14 other

148 values were between 1.21 and 1.58). In addition, all 25 model parameters (namely, total tree

149 length, the six pairs of parameters for the presence and absence of RFs on each of the six regions,

150 the alpha shape parameter for each of the six regions and the relative rates for each of the six 
151 regions) had PSRF values of less than 1.14. These PSRF values suggest good convergence of the

152 two runs (i.e. less than the PSRF threshold of 1.2 as suggested by Gelman et al., 1995). As noted

153 in the MrBayes output, the MrBayes PSRF values should be treated as a rough guide to

154 convergence as not all assumptions are met for a PSRF convergence diagnostic in the

155 phylogenetic context. Another convergence diagnostic, the standard deviation of split

156 frequencies between simultaneous runs, was close to zero $(<0.08)$, confirming convergence. Six

157 additional Bayesian analyses were carried out for each of the six regions individually to produce

158 phylogenetic trees for each region, with similar convergence diagnostics. The statistical support

159 for groups in a Bayesian phylogenetic tree is expressed as a posterior probability ranging from

1600.0 to 1.0 , rather than the zero to 100 scale used in other phylogenetic approaches. RFLP

161 groupings were assigned based on posterior support being present for each grouping.

162 Phylogenetic tree diagrams were produced using the Dendroscope program (Huson et al., 2007).

163

164 3. Results and discussion

165 The genetic diversity of $p m p$-encoding genes from fifty two C. abortus strains were

166 investigated by PCR-RFLP. Six primer pairs were used to PCR-amplify approximately 55kb

167 spanning the $18 \mathrm{pmp}$-encoding genes and corresponding intergenic regions. PCR products of the

168 expected size were obtained from 48 unique strains using primer set BA and 39, 43, 32, 47 and

16952 unique strains using primer sets $\mathrm{EH}, \mathrm{HG}, \mathrm{G}, 16-17$ and $18 \mathrm{D}$ respectively. PCR amplification

170 was more variable when primer pairs generating larger PCR fragments $(>10 \mathrm{~kb})$ were used,

171 probably due to the shearing of genomic DNA during DNA extraction. Where PCR amplification

172 was poor or absent, the presence of pmp-encoding loci was confirmed by PCR amplification of

173 the region as smaller PCR fragments (data not shown). 
175 with the four REs HaeIII, AluI, RsaI and MboII and resolving RFs within the size range of $50 \mathrm{bp}$

176 to $10 \mathrm{~kb}$ on an agarose gel. RFLP patterns for individual strains were scored based on the

177 presence or absence of each RF and phylogenetic trees were generated to graphically represent

178 strain similarity (Figure 1, Supplementary figures 1-6). Strains were assigned to RFLP groups

179 based on the posterior probability assigned to each clade (Table 3). The number of genotypes

180 assigned at each pmp-encoding locus varied from two genotypes observed at the $18 \mathrm{D}$ locus to 5

181 genotypes observed at the pmp16-17 locus. At each of the six loci, the majority of strains

182 belonged to a single genotype, typified by the reference strain S26/3. Based on the assumption

183 that different RFLP patterns indicate that nucleotide changes have occurred in the gene locus,

184 either at the RE recognition site or by nucleotide insertions or deletions in the intervening gene

185 regions, the majority of strains belonging to a single genotype similar to S26/3 suggests a high

186 degree of conservation both of the DNA sequence and the arrangement of the pmp-encoding 187 genes.

RFLP profiles of the 18D locus were identical in all strains except AB7 and FAG which

189 formed a discrete cluster with a posterior probability of 0.98 based on a single unique restriction

190 fragment which was observed when 18D PCR products were digested with the RE RsaI (data not

191 shown). The relative rate of evolution, calculated by modelling RFLP data using a gamma

192 distribution while constraining each region to estimate the same tree topology was 0.135 ,

193 suggesting that this gene locus was evolving more slowly compared to other pmp-encoding gene

194 loci (Table 4). Pmp 18D exhibits high levels of DNA and amino acid sequence conservation

195 across the Chlamydiaceae. Putative roles based on the timing of expression in vitro and the

196 inhibition of in vitro infection using neutralizing antibodies against Pmp18D suggest a role in the 
197 adhesion of $C$. pneumoniae and $C$. trachomatis to host cells (Crane et al., 2006; Wehrl et al.,

198 2004; Mölleken et al., 2010). However the expression of the gene early in the replication cycle

199 suggests that this protein may have an additional function during the late replicative/early

200 differentiation phase (Wheelhouse et al., 2009).

201 Other pmp-encoding loci showed a greater degree of gene heterogeneity with discrete

202 genotypes observed in each region. Strains S404/5, S507 and S82/3 (posterior probability $=0.70$ )

203 formed a discrete grouping in region EH (Table 3). Strains Zar-2B and AO-4 (posterior

204 probability $=0.72$ ) and strains AB7 and C94/2 (posterior probability $=0.56$ ) formed a discrete

205 grouping in region $\mathrm{HG}$ (Table 3). In C. trachomatis $\mathrm{PmpH}$ has been implicated in the

206 mechanisms of pathogenesis due to the observation that $\mathrm{pmpH}$ gene sequences diverged into 3

207 clades that were consistent with the three different disease pathotypes, urogenital, ocular and

208 lymphogranuloma venereum (Stothard et al., 2003; Gomes et al., 2006). It is still unknown if the

209 grouping in the region HG in C. abortus has a similar pathophysiological basis.

210 Strains AO-4 and Zar-5 formed a discrete grouping at regions $\mathrm{G}$ (posterior probability =

211 0.77) (Table 3) and strains C94/1 and C94/2 (posterior probability = 0.83), strains C1/98, C17/98

212 and C9/98 (posterior probability $=0.55$ ) and strains 15 and 532 (posterior probability $=0.51$ )

213 formed a discrete grouping in region 16-17 (Figure 1, Table 3). The relative rate of evolution in

214 pmpG and pmp16-17 regions was predicted to be 1.488 and 1.468 respectively. The higher

215 relative rate of evolution of the pmp G family of proteins, a family that has a number of

216 paralogues present in $C$. abortus, suggests that the $p m p G$ and pmp16-17 may be under different

217 selective pressures to other pmp-encoding genes. It is unclear whether these genes have a high

218 relative rate of evolution because they contribute to antigenic variance or whether they are

219 redundant in the infection cycle. 
Two strains, LLG and POS, showed a markedly different genotype to other strains with

221 posterior support observed for the discrete grouping of strains LLG and POS at pmp-encoding

222 regions BA (posterior probability $=0.59), \mathrm{EH}($ posterior probability $=0.87), \mathrm{HG}$ (posterior

223 probability $=0.79), \mathrm{G}($ posterior probability $=0.62)$ and $16-17($ posterior probability $=0.91)$.

224 This was the only RFLP group that could be correlated with geographical location, with both

225 strains originating from Greece. However LLG and POS are not typical Greek strains having

226 been identified as variant strains by MLVA (Laroucau et al., 2009) and the DNA sequencing of

227 the 23S domain I rRNA (Siarkou et al., 2002). Phenotypic differences have been observed in the

228 inclusion morphology and polypeptide profiles of these two strains, in mouse cross-protection

229 experiments and in antibody cross-reactivity to variable segments of MOMP (Vretou et al., 1996;

230 Vretou et al., 2001). Studies in pregnant mice have demonstrated these strains to be different

231 from other C. abortus strains in terms of their ability to colonise the placenta and fetus

232 (Bouakane et al., 2003). Furthermore, mouse protection studies have shown a decreased

233 effectiveness of the live 1B vaccine in terms of organism recovery (Bouakane et al., 2005).

234 However, the differences observed did not prevent inactivated AB7-based vaccines from

235 providing protection against heterologous challenge with LLG (Caro et al., 2003).

This study presents the first assessment of the genetic diversity that exists within the 18

237 pmp-encoding genes of C. abortus. The pmp-encoding regions of C. abortus were largely

238 homogeneous with the majority of strains exhibiting genotypes similar to reference strain S26/3.

239 However, novel genotypes were identified in all pmp-encoding loci. Although the biological

240 significance of this variation in terms of pathogenesis is currently unknown, this sequence

241 heterogeneity should be an important consideration when using pmps as the basis for diagnostic

242 test or vaccine development. 


\section{Acknowledgements}

This work was funded by grant no. BB/E018939/1 from the Biological and

246 Biotechnology Sciences Research Council (BBSRC) and by the Scottish Government Rural and

247 Environmental Research and Analysis Directorate (RERAD).

249 Conflict of interest statement

$250 \quad$ The authors declare no conflict of interest.

\section{References}

253 Bouakane, A., Benchaïeb, I., Rodolakis, A. 2003. Abortive potency of Chlamydophila abortus in pregnant mice is not directly correlated with placental and fetal colonization levels. Infect. Immun. 71, 7219-7222.

Bouakane, A., Rekiki, A., Rodolakis, A. 2005. Protection of pregnant mice against placental and splenic infection by three strains of Chlamydophila abortus with a live 1B vaccine. Vet. Rec. 157, 771-774.

Bryant, D., Moulton, V., 2004. Neighbor-net: an agglomerative method for the construction of phylogenetic networks. Mol. Biol. Evol. 21, 255-265.

261 Caro, M.R., Ortega, N., Buendia, A.J., Gallego, M.C., del Rio, L., Cuello, F., Salinas, J., 2003.

262 Relationship between the immune response and protection conferred by new designed 263 inactivated vaccines against ovine enzootic abortion in a mouse model. Vaccine. 21, $264 \quad 3126-3136$. 
Crane, D.D., Carlson, J.H., Fischer, E.R., Bavoil, P., Hsia, R.C., Tan, C., Kuo, C.C., Caldwell, H.D., 2006. Chlamydia trachomatis polymorphic membrane protein D is a speciescommon pan-neutralizing antigen. Proc. Natl. Acad. Sci. U.S.A. 103, 1894-1899.

Denamur, E., Sayada, C., Souriau, A., Orfila, J., Rodolakis, A., Elion, J., 1991. Restriction pattern of the major outer-membrane protein gene provides evidence for a homogeneous invasive group among ruminant isolates of Chlamydia psittaci. J. Gen. Microbiol. 137, $2525-2530$.

Everett, K.D.E., Bush, R.M., Andersen, A.A., 1999. Emended description of the order Chlamydiales, proposal of Parachlamydiaceae fam. nov. and Simkaniaceae fam. nov., each containing one monotypic genus, revised taxonomy of the family Chlamydiaceae, including a new genus and five new species, and standards for the identification of organisms. Int. J. Syst. Bacteriol. 49, 415-440.

Gelman, A., Carlin, J.B., Stern, H.S., Rubin, D.B., 1995. Bayesian data analysis. Chapman \& Hall, London, UK.

Gomes, J.P., Nunes, A., Bruno, W.J., Borrego, M.J., Florindo, C., Dean, D., 2006. Polymorphisms in the nine polymorphic membrane proteins of Chlamydia trachomatis across all serovars: evidence for serovar Da recombination and correlation with tissue tropism. J. Bacteriol. 188, 275-286.

Graham, S.P., Jones, G.E., MacLean, M., Livingstone, M., Entrican, G., 1995. Recombinant ovine interferon gamma inhibits the multiplication of Chlamydia psittaci in ovine cells. J. Comp. Pathol. 112, 185-195. 
Henderson, I.R., Navarro-Garcia, F., Desvaux, M., Fernandez, R.C., a'Aldeen, D., 2004. Type V protein secretion pathway: the autotransporter story. Microbiol. Mol. Biol. Rev. 68, 692744.

Huelsenbeck, J.P., Ronquist, F., 2001. MRBAYES: Bayesian inference of phylogenetic trees. Bioinformatics. 17, 754-755.

Huson, D.H., Bryant, D., 2006. Application of phylogenetic networks in evolutionary studies. Mol. Biol. Evol. 23, 254-267.

Huson, D.H., Richter, D.C., Rausch, C., Dezulian, T., Franz, M., Rupp, R., 2007. Dendroscope An interactive viewer for large phylogenetic trees. BMC Bioinformatics. 8, 460.

Laroucau, K., Vorimore, F., Bertin, C., Mohamad, K.Y., Thierry, S., Hermann, W., Maingourd, C., Pourcel, C., Longbottom, D., Magnino, S., Sachse, K., Vretou, E., Rodolakis, A., 2009. Genotyping of Chlamydophila abortus strains by multilocus VNTR analysis. Vet. Microbiol. 137, 335-344.

Livingstone, M., Entrican, G., Wattegedera, S., Buxton, D., McKendrick, I.J., Longbottom, D., (2005) Antibody responses to recombinant protein fragments of the major outer membrane protein and polymorphic outer membrane protein POMP90 in Chlamydophila abortus-infected pregnant sheep. Clin. Diagn. Lab. Immunol. 12, 770-777.

Longbottom, D., Coulter, L.J., 2003. Animal chlamydioses and zoonotic implications. J. Comp. Pathol. 128, 217-244. 
305

306

307

308

309

310

311

312

313

314

315

316

317

Longbottom, D., Livingstone, M., 2006. Vaccination against chlamydial infections of man and animals. Vet. J. 171, 263-275.

Longbottom, D., Russell, M., Dunbar, S.M., Jones, G.E., Herring, A.J., 1998. Molecular cloning and characterization of the genes coding for the highly immunogenic cluster of $90-$ kilodalton envelope proteins from the Chlamydia psittaci subtype that causes abortion in sheep. Infect. Immun. 66, 1317-1324.

Longbottom, D., Russell, M., Jones, G.E., Lainson, F.A., Herring, A.J., 1996. Identification of a multigene family coding for the $90 \mathrm{kda}$ proteins of the ovine abortion subtype of Chlamydia psittaci. FEMS Microbiol. Lett. 142, 277-281.

Mölleken, K., Schmidt, E., Hegemann, J.H., 2010. Members of the Pmp protein family of Chlamydia pneumoniae mediate adhesion to human cells via short repetitive peptide motifs. Mol. Microbiol. 78, 1004-1017.

Mygind, T., Vandahl, B., Pedersen, A.S., Christiansen, G., Höllsberg, P., Birkelund, S., 2004. Identification of an in vivo $\mathrm{CD} 4+\mathrm{T}$ cell-mediated response to polymorphic membrane proteins of Chlamydia pneumoniae during during experimental infection. FEMS Immunol. Med. Microbiol. 40, 129-137.

Pannekoek, Y., Dickx, V., Beeckman, D.S.A., Jolley, K.A., Keijzers, W.C., Vretou, E., Maiden, M.C.J., Vanrompay, D., van der Ende, A. 2010. Multi Locus Sequence Typing of Chlamydia reveals an association between Chlamydia psittaci Genotypes and Host species. PLOS One 5: e14179. 
Sachse, K., Vretou, E., Livingstone, M., Borel, N., Pospischil, A., Longbottom, D., 2009. Recent developments in the laboratory diagnosis of chlamydial infections. Vet. Microbiol. 135, $2-21$.

Salinas, J., Souriau, A., Cuello, F., Rodolakis, A., 1995. Antigenic diversity of ruminant Chlamydia psittaci strains demonstrated by the indirect microimmunofluorescence test with monoclonal antibodies. Vet. Microbiol. 43, 219-226.

Siarkou, V., Lambropoulos, A.F., Chrisafi, S., Kotsis, A., Papadopoulos, O., 2002. Subspecies variation in Greek strains of Chlamydophila abortus. Vet. Microbiol. 85, 145-157.

Stothard, D.R., Toth, G.A., Batteiger, B.E., 2003. Polymorphic membrane protein H has evolved in parallel with the three disease-causing groups of Chlamydia trachomatis. Infect. Immun. 71, 1200-1208.

Thomson, N.R., Yeats, C., Bell, K., Holden, M.T., Bentley, S.D., Livingstone, M., CerdenoTarraga, A.M., Harris, B., Doggett, J., Ormond, D., Mungall, K., Clarke, K., Feltwell, T., Hance, Z., Sanders, M., Quail, M.A., Price, C., Barrell, B.G., Parkhill, J., Longbottom, D., 2005. The Chlamydophila abortus genome sequence reveals an array of variable proteins that contribute to interspecies variation. Genome Res. 15, 629-640.

Vretou, E., Loutrari, H., Mariani, L., Costelidou, K., Eliades, P., Conidou, G., Karamanou, S., Mangana, O., Siarkou, V., Papadopoulos, O., 1996. Diversity among abortion strains of Chlamydia psittaci demonstrated by inclusion morphology, polypeptide profiles and monoclonal antibodies. Vet. Microbiol. 51, 275-289. 
345 Vretou, E., Psarrou, E., Kaisar, M., Vlisidou, I., Salti-Montesanto, V., Longbottom, D., 2001.

346 Identification of protective epitopes by sequencing of the major outer membrane protein

347 gene of a variant strain of Chlamydia psittaci serotype 1 (Chlamydophila abortus). Infect.

$348 \quad$ Immun. 69, 607-612.

349 Wehrl, W., Brinkmann, V., Jungblut, P.R., Meyer, T.F., Szczepek, A.J., 2004. From the inside

350 out - processing of the Chlamydial autotransporter PmpD and its role in bacterial

351 adhesion and activation of human host cells. Mol. Microbiol. 51, 319-334.

352 Wheelhouse, N., Aitchison, K., Spalding, L., Livingstone, M., Longbottom, D., 2009.

353 Transcriptional analysis of in vitro expression patterns of Chlamydophila abortus

354 polymorphic outer membrane proteins during the chlamydial developmental cycle. Vet.

$355 \quad$ Res. $40,47$.

356 


\section{Figure Legends}

358

359 Figure 1.

360

(A) C. abortus RFLP profiles generated following RE digestion of polymorphic

361 membrane protein 16-17 locus PCR products from twenty representative strains; 1, DC1. 2, POS.

362 3, LLG. 4, 8385. 5, S152/3. 6, FAG. 7, S26/3. 8, S26/3. 9, 53. 10, C94/1. 11, Z339. 12, AO-2.

363 13, T28. 14, Syva-1. 15, S26/3. 16, AO-7. 17, T19. 18, AO-4. 19, 532. 20, 15. The RFs used for

364 analysis have been highlighted. The size of the upper and lower RF is indicated at the side of the

365 gel. (B) Evolutionary relationships of C. abortus strains at the 16-17 locus. The posterior

366 probability of discrete groupings is indicated by the number at the node. 
Table 1. C. abortus strains used for PCR-RFLP analysis

\begin{tabular}{lll}
\hline Country of & Host & Strain \\
origin & species & \\
\hline France & Sheep & AB7 \\
Germany & Cow & 03DC34, 03DC36, C11/98, Z339 \\
& Goat & 532 \\
& Pig & DC12 \\
& Sheep & 53, C1/98, C2/98, C7/98, C9/98, C10/98, C17/98, DC1, DC4, DC7 \\
& Goat & FAG, LLG \\
Greece & Sheep & POS \\
& Sheep & C94/1, C94/2, C95/23, C95/27, VS88/576 \\
Ireland & Cow & LV350/93 \\
Italy & Goat & C21/98 \\
Namibia & Goat & Syva-1 \\
Spain & Sheep & AO-2, AO-3, AO-4, AO-7, Zar-2B, Zar-5 \\
& Goat & 15 \\
Tunisia & Sheep & $83 / 12,86 / 30,90 / 345$, A22, H574, S3/3, S26/3, S82/3, S95/3, \\
UK & & S124/3A, S152/3, S404/5, S507, T17, T19, T20, T28 \\
& & \\
& &
\end{tabular}


Table 2. Primers used for the PCR-amplification of pmp-encoding genes.

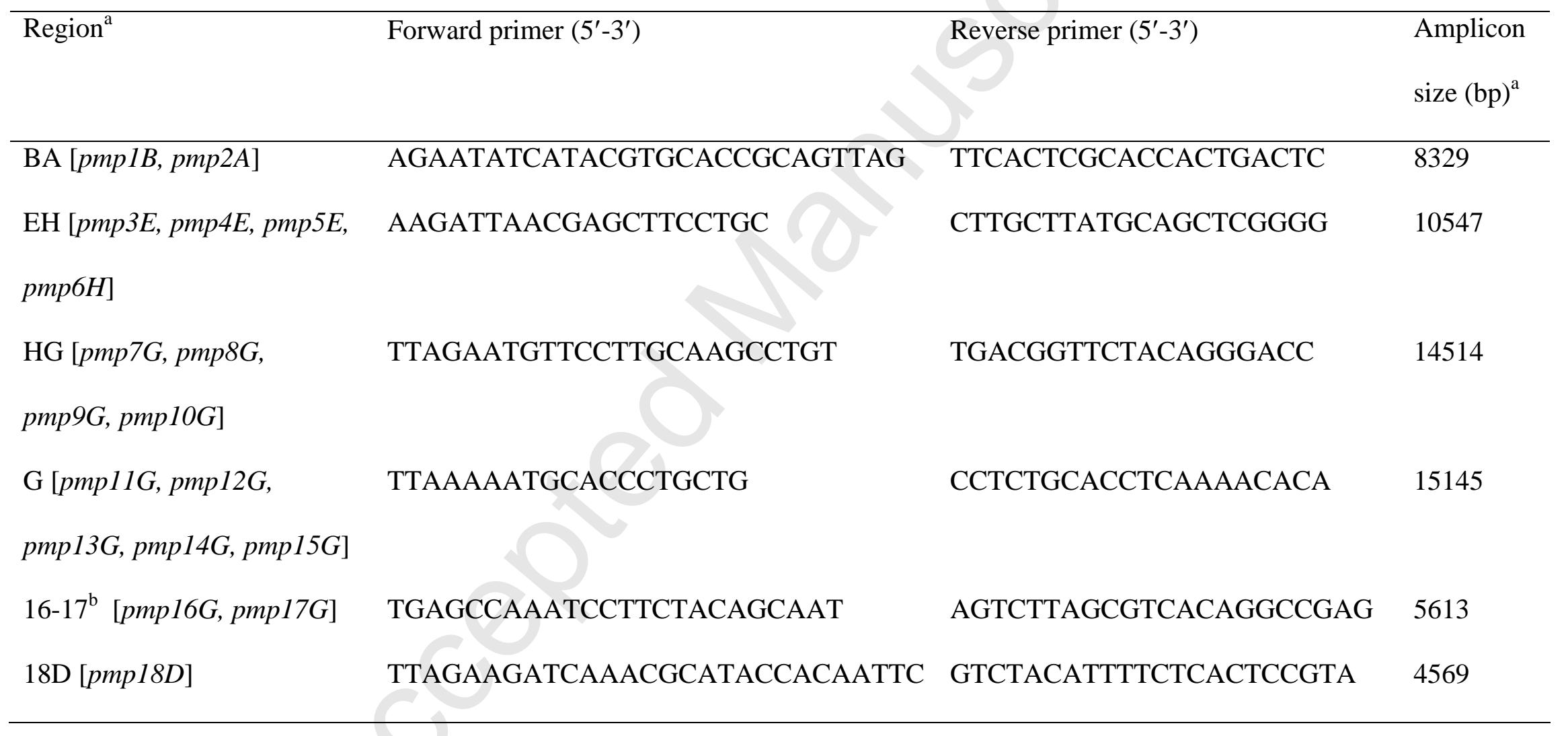

\footnotetext{
${ }^{a}$ Based on C. abortus S26/3 genome sequence [NC_004552]
}

${ }^{\mathrm{b}}$ Primers have been described previously as S5765 and S2429 (Longbottom et al., 1998) 
Table 3. C. abortus strains organized by RFLP grouping at each pmp-encoding locus.

\begin{tabular}{|c|c|c|c|}
\hline Locus & $\begin{array}{l}\text { RFLP } \\
\text { group }\end{array}$ & 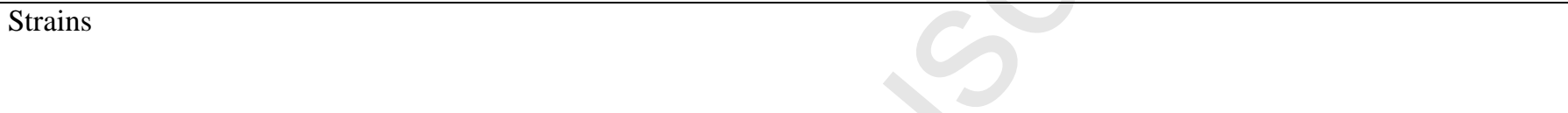 & PSRF \\
\hline $\mathrm{BA}$ & 1 & $\begin{array}{l}\text { 03DC34, 03DC36, 83/12, 86/30, 90/345, 532, A22, AB7, AO-2, AO-4, AO-7, C1/98, C2/98, C7/98, C9/98, C10/98, C17/98, } \\
\text { C21/98, C94/1, C94/2, C95/23, C95/27, DC1, DC4, DC7, FAG, H574, 15, LV350/93, Syva-1, S3/3, S26/3, S82/3, S95/3, } \\
\text { S124/3A, S152/3, S404/5, S507, T17, T19, T20, T28, Zar-2B, Z339 }\end{array}$ & unresolved \\
\hline & 3 & $\begin{array}{l}\text { LLG, POS } \\
\text { C11/98, } 53\end{array}$ & $\begin{array}{l}0.59 \\
0.75\end{array}$ \\
\hline $\mathrm{EH}$ & 1 & $\begin{array}{l}\text { 03DC34, 53, 532, 83/12, 86/30, 90/345, A22, AB7, AO-2, AO-4, AO-7, C2/98, C7/98, C9/98, C10/98, C17/98, C21/98, } \\
\text { C94/1, C94/2, C95/23, C95/27, DC1, DC4, DC7, DC12, FAG, LV350/93, S3/3, S26/3, S95/3, S124/3A, S152/3, T17, T19, } \\
\text { T20, T28, Zar-2B, Z339 }\end{array}$ & unresolved \\
\hline & $\begin{array}{l}2 \\
3\end{array}$ & $\begin{array}{l}\text { LLG, POS } \\
\text { S404/5, S507, S82/3 }\end{array}$ & $\begin{array}{l}0.87 \\
0.70\end{array}$ \\
\hline HG & 1 & $\begin{array}{l}\text { 03DC34, 53, 532, 83/12, 86/30, 90/345, A22, AO-2, AO-7, C2/98, C7/98, C9/98, C10/98, C17/98, C21/98, C94/1, C95/23, } \\
\text { C95/27, DC1, DC4, DC7, FAG, H574, LV350/93, S3/3, S26/3, S82/3, S95/3, S124/3A, S152/3, S404/5, S507, T17, T19, T20, } \\
\text { T28, Z339 }\end{array}$ & unresolved \\
\hline & 2 & LLG, POS & 0.79 \\
\hline & 3 & $\mathrm{AO}-4, \mathrm{Zar}-2 \mathrm{~B}$ & 0.72 \\
\hline & 4 & AB7, C94/2 & 0.56 \\
\hline G & 1 & 53, 532, 83/12, 86/30, 90/345, A22, AB7, AO-7, C7/98, C9/98, C21/98, DC1, DC7, FAG, LV350/93, S3/3, S26/3, S82/3, & unresolved \\
\hline
\end{tabular}




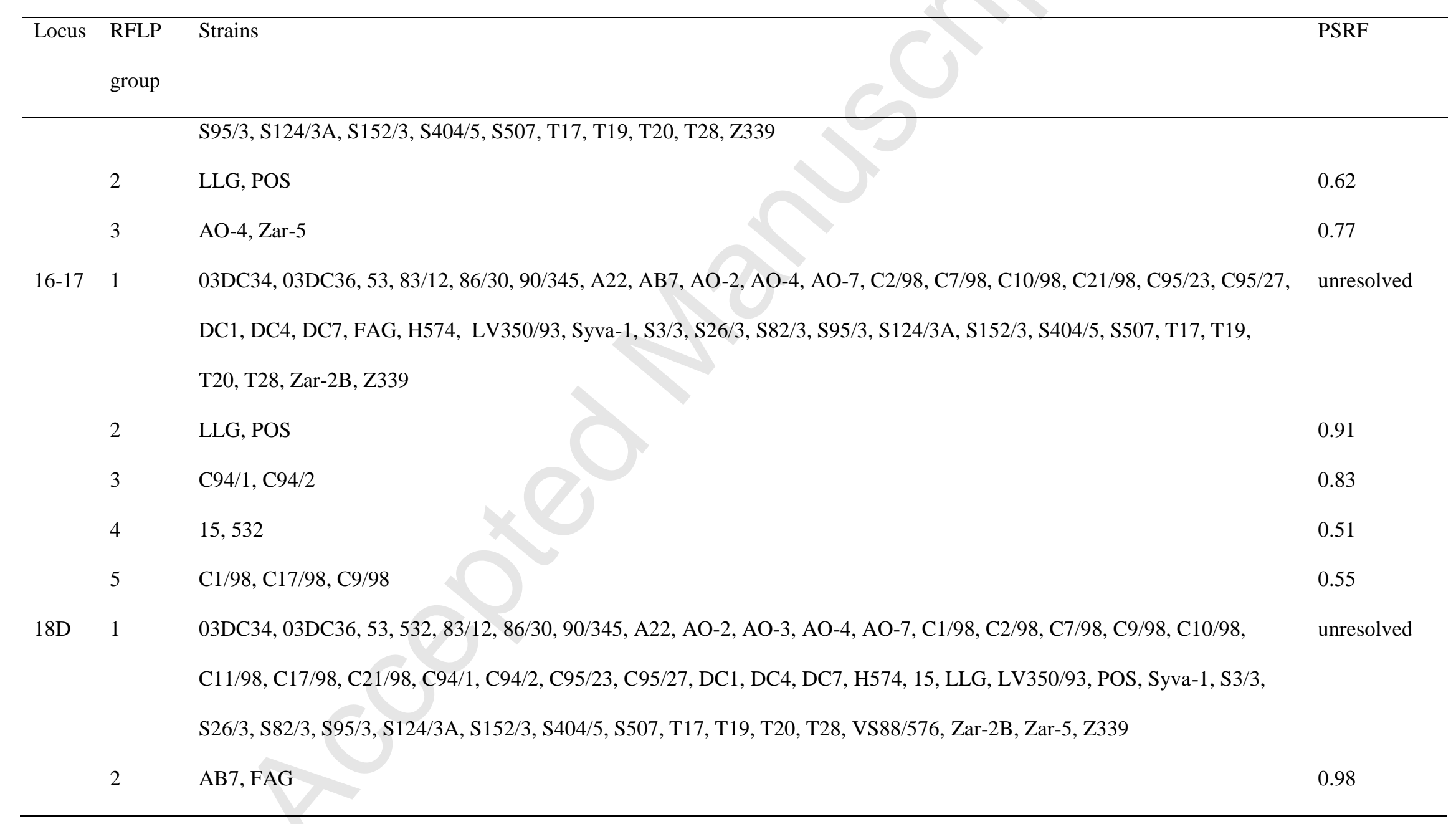


Table 4. Relative evolutionary rates for $p m p$-encoding gene loci

\begin{tabular}{llll}
\hline Region & Mean & 95\% confidence & $95 \%$ confidence \\
& & interval, lower & interval, upper \\
& & limit & limit \\
& & & 0.770 \\
BA & 0.425 & 0.142 & 1.406 \\
EH & 0.928 & 0.569 & 1.114 \\
HG & 0.874 & 0.648 & 1.885 \\
G & 1.488 & 1.105 & 1.948 \\
$16-17$ & 1.468 & 1.005 & 0.368 \\
$18 D$ & 0.135 & 0.015 & \\
\hline
\end{tabular}


A Size

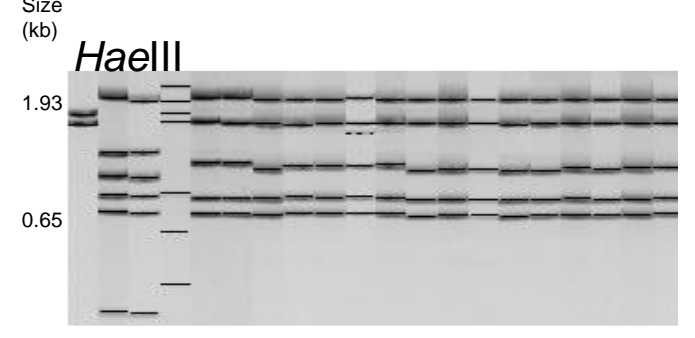

Alul

0.51

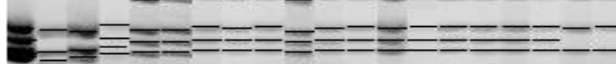

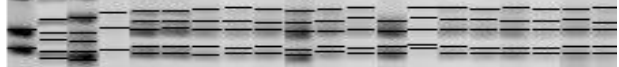

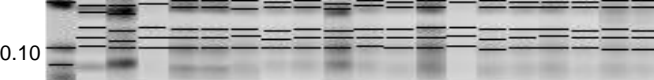

\section{Rsal}

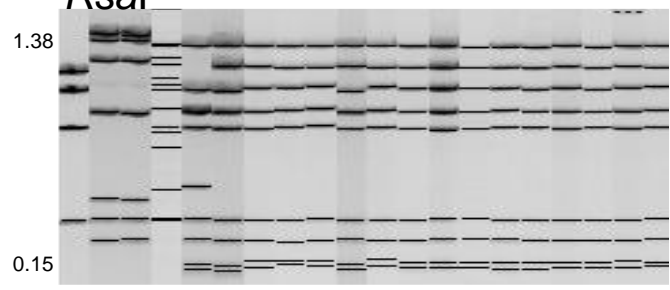

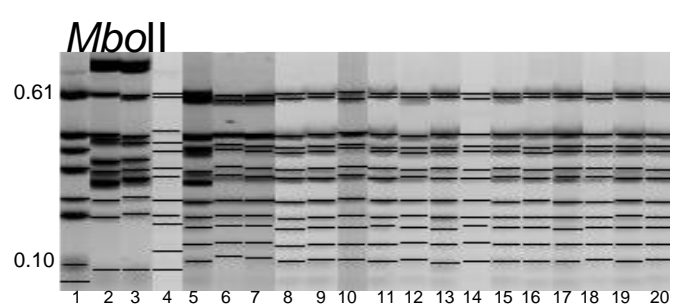

B

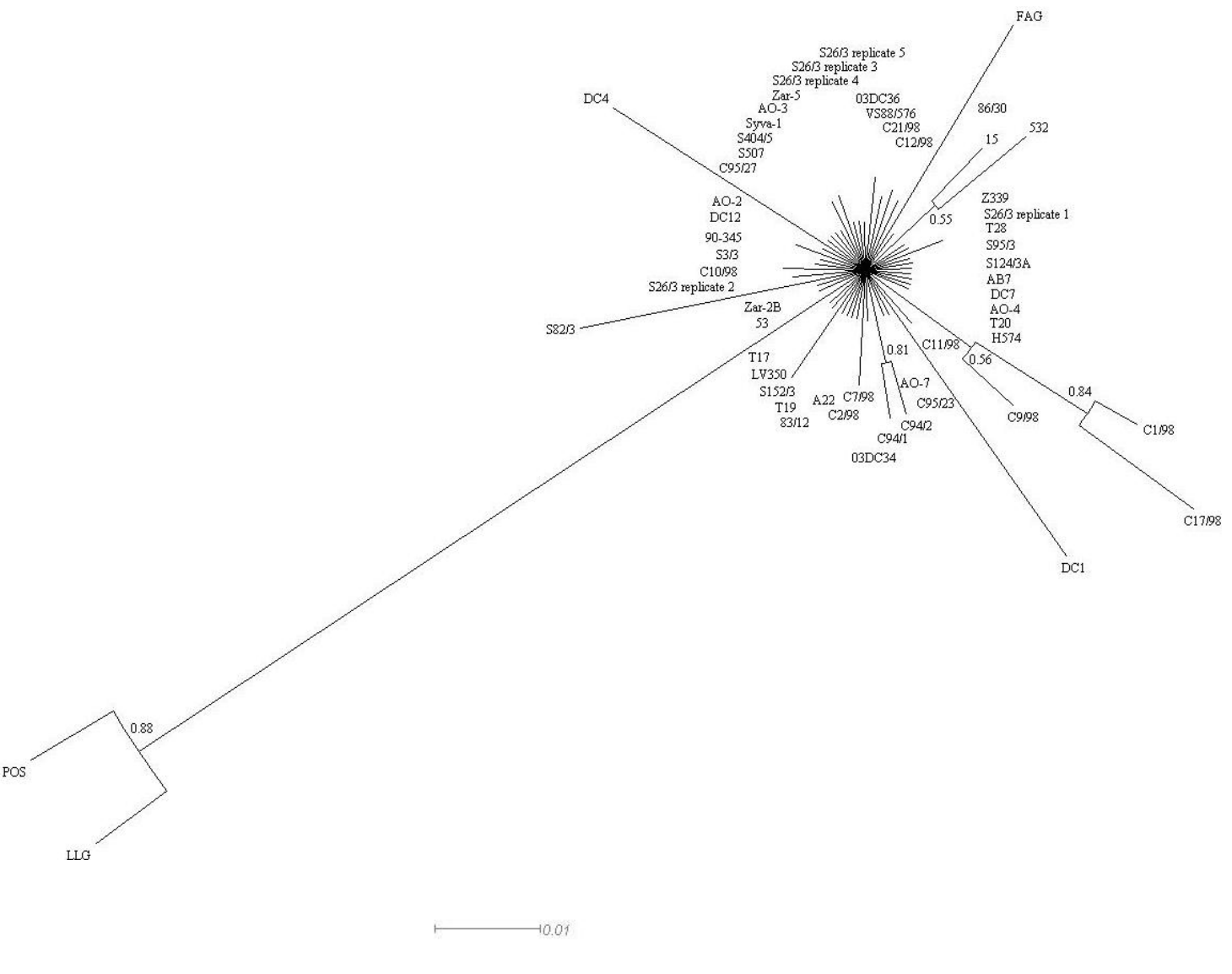

